\title{
What's ontology got to do with it? On nature and knowledge in a political ecology of the 'green economy'
}

\author{
Sian Sullivan ${ }^{1}$ \\ Bath Spa University, UK
}

\begin{abstract}
Contemporary market-based (i.e. neoliberal) 'green economy' approaches to environmental degradation emphasise exchanges whereby quantified units of environmental harm are traded or 'offset' for compensating units of environmental health. Also encouraged is a view that economic growth can be 'greened' through 'decoupling' economic value from material ecological realities. Such approaches tend to frame biophysical natures in terms of aggregates, such as an 'aggregate natural capital rule' and 'net zero carbon.' Naturesbeyond-the-human are thereby understood and enacted as calculable, exchangeable, substitutable and commensurable between different spatial and temporal sites, making up an 'aggregate' or 'net' value overall. This article uses a comparative cross-cultural engagement to problematize ontological assumptions regarding the nature of nature underscoring the rationality of these aggregating and offsetting 'solutions.' Drawing on literatures from environmental anthropology and environmental ethics, combined with ethnographic material from long-term field research in north-west Namibia, the article considers elements of alternative cultural ontologies and the ways these may give rise to a different array of practices with value for conceiving and generating 'sustainability.' It adheres to a critical political ecology perspective in understanding the ways that power structures the ontologies that become both privileged and occluded in neoliberal strategies for green economy governance. In doing so, the article argues that sensitivity to the ontological politics through which spaces and entities are defined and known and which thereby shape environmental conflicts, may be key to recognising with more depth the sometimes significantly different 'natures' being struggled over in such conflicts.
\end{abstract}

Key words: ontology; green economy; offsetting; decoupling; sustainability; value; natures-beyond-thehuman; neoliberalism; political ecology

\section{Résumé}

Les approches de la dégradation de l'environnement fondées sur le marché et l'économie verte mettent l'accent sur les échanges, dans le cadre desquels des unités quantifiées de dommages à l'environnement sont échangées ou «compensées» pour compenser des unités de santé environnementale. On encourage également l'idée que la croissance économique peut être «vernie» par le biais du «découplage» de la valeur économique des réalités écologiques matérielles. De telles approches tendent à encadrer les natures biophysiques en termes d'agrégats, tels qu'une «règle du capital naturel agrégé» et un «carbone zéro net». Les natures-au-delà de l'humain sont ainsi comprises et promulguées comme calculables, échangeables, substituables et commensurables entre différents sites spatiaux et temporels, constituant une valeur «agrégée» ou «nette». Cet article utilise un engagement interculturel comparatif pour problématiser les hypothèses ontologiques concernant la nature de la nature, soulignant la rationalité de ces «solutions» d'agrégation et de compensation.

\footnotetext{
${ }^{1}$ Prof. Sian Sullivan, College of Liberal Arts, Bath Spa University, UK. Email: s.sullivan "at" bathspa.ac.uk. Acknowledgements: I gratefully acknowledge communications with numerous people whilst conducting field research in west Namibia in the course of writing this article, as well as funding from the UK's Arts and Humanities Research Council (AH/K005871/2, www.futurepasts.net) and the Leverhulme Trust (RP2012-V-041, http://thestudyofvalue.org). Invaluable translation and logistical support was provided in Namibia by Simson !Uri-||khob, Welhemina Suro Ganuses, Filemon |Nuab, Ezegiel |Awarab, Elfriede Gaeses, Andrew Botelle, Eugène Marais and Jeff Muntifering, for which many thanks. Thank you to Mike Hannis, Rob Fletcher and two anonymous reviewers, who read and commented on earlier versions of the article and kindly pushed me on certain aspects. Finally, I am grateful to Tor Arve Benjaminsen and Connor Cavanagh for the invitation to give a keynote paper at the workshop at which the material here was first presented. This is the first article in Connor Cavanagh and Tor Benjaminsen (eds.) 2017. "Political ecologies of the green economy", Special Section of the Journal of Political Ecology, 24: 200-341.
} 
L'article s'appuie sur des littératures tirées de l'anthropologie environnementale et de l'éthique environnementale, combinées à du matériel ethnographique issu de recherches sur le terrain à long terme dans le nord-ouest de la Namibie. Nous considérons des éléments d'ontologies culturelles alternatives, et les manières dont celles-ci peuvent donner lieu à une gamme différente de pratiques, avec une valeur pour concevoir et générer la «durabilité». L'article adopte une perspective d'écologie politique critique pour comprendre les façons dont le pouvoir structure les ontologies qui deviennent à la fois privilégiées et occultées dans les stratégies néolibérales de gouvernance de l'économie verte. Ce faisant, elle fait valoir que la sensibilité à la politique ontologique par laquelle les espaces et les entités sont définis et connus et qui forment ainsi les conflits environnementaux, peut être essentielle pour reconnaître et comprendre les «natures» parfois différentes, avec plus de profondeur.

Mots clés: ontologie; économie verte; compensation; découplage; durabilité; valeur; natures-au-delà de l'humain; néolibéralisme; écologie politique

\section{Resumen}

Los acercamientos contemporáneos enfocados en el desgaste ambiental desde la perspectiva de mercado de "economía verde", hacen énfasis en los intercambios mediante los cuales las unidades cuantificadas de daño ambiental son intercambiadas por compensaciones en unidades de salud ambiental. Estos acercamientos fomentan una perspectiva en que el crecimiento económico puede "hacerse verde" a través de la "desarticulación" del valor económico y la realidad material ecológica. Dichos enfoques tienden a crear un marco para agrupar las naturalezas biofísicas, tales como la "norma de conjunto del capital natural" y "red cero carbón". Las naturalezas más allá de lo humano son por lo tanto, entendidas y representadas como calculables, intercambiables, sustituibles y conmensurables entre los diferentes sitios espaciales y temporales, consolidando así un "conjunto" o "red" de valor. Este artículo se basa en una aproximación comparativa intercultural para problematizar supuestos ontológicos sobre la naturaleza de la naturaleza enfatizando la racionalidad de estas "soluciones" agrupadoras y compensatorias. Combinando literatura de antropología ambiental y ética ambiental con material etnográfico de un largo periodo de trabajo de campo en el noroeste de Namibia, el artículo considera elementos de ontologías culturales alternativas y las formas en que estas pueden dar pie a la formación de prácticas con valor para generar y concebir "sustentabilidad". El artículo se apega a una perspectiva de ecología política crítica para entender las formas que el poder estructura las ontologías que se vuelven tanto privilegiadas como marginalizadas en estrategias neoliberales por la gobernanza de economía verde. Para lograrlo, el artículo argumenta que la sensibilidad ante las políticas ontológicas a través de las cuales los espacios y las entidades son definidas y conocidas, y que por lo tanto definen conflictos ambientales, pueden ser una clave para el reconocimiento y entendimiento con más profundidad de las diferentes -en algunos casos importantes- naturalezas que son afectadas por dichos conflictos.

Palabras clave: Ontología, economía verde, compensación, desarticulación, sustentabilidad, valor, naturalezas más allá del humano, neoliberalismo, ecología política.

\section{An ethnographic opening ${ }^{2}$}

When completing two years of doctoral field research in west Namibia in 1996 I started reading Marion Zimmer Bradley's 1983 novel The mists of Avalon (Zimmer Bradley 1993(1983)). Centred on Glastonbury Tor, a striking hill that rises from the surrounding Somerset Levels in west England and visible from miles around, the book has become celebrated as a feminist retelling of the Arthurian legends. Glastonbury today is considered by New Agers to be the heart chakra of the planet (Bowman 2007: 309). ${ }^{3}$ It is perhaps best known now for the annual Glastonbury Festival that for 40 years has commemorated the summer solstice. ${ }^{4}$

\footnotetext{
2 This article began life as a keynote paper given at the Norwegian Network for Political Ecology workshop on Political ecologies of the green economy, Norwegian University of Life Sciences, December 2014 http://www.ntnu.edu/politicalecology/political-ecologies-of-the-green-economy.

${ }^{3}$ Numerous websites and texts attest to this perceived reality. See, for example, http://earthchakras.org/glastonbury.php, accessed 29 October 2015.

${ }^{4}$ See http://www.glastonburyfestivals.co.uk/, last accessed 29 October 2015.
} 
In The Mists of Avalon two Glastonburys exist simultaneously. One is the Glastonbury of the establishment of a patriarchal Christian church, associated with the suppression and denigration of old pagan cyclical ceremonies of fertility and renewal. To this day, a now-ruined St. Michael chapel dating to the $15^{\text {th }}$ century is positioned on the highest point of the Tor, constructed on the remains of church-associated buildings dating to several centuries earlier. ${ }^{5}$ The second Glastonbury in The mists of Avalon is the druidic Isle of Avalon, whose pagan sacred knowledge is held in particular by a matriarchal community living on the Tor. In the context of the growing Christian and patriarchal power in which the book is set, this older druidic community can only be seen and accessed with knowledge of the right words and protocols that open the mists surrounding the Tor. These mists otherwise act as a veil between the matriarchal and pagan epistemic community situated on the Tor, and the parallel patriarchal and Christian certainties with which this community is coming to be replaced.

I was reminded of this fable recently whilst conducting oral history research with two elders in northwest Namibia. In this research I have been recording childhood memories and GPS coordinates for places and histories that have been erased from official discourses regarding land where families used to live. This work constitutes something of what Anna Tsing (2014: 13) describes as "historical retracing": "walking the tracks of the past even in the present" to draw out "the erasure of earlier histories in assessments of the present", so as to fill "the present with the traces of earlier interactions and events" (also see Sullivan and Hannis 2016). Such research pulls into the open occluded and alternative knowledges, practices and experiences that continue to 'haunt' the present despite their diminution through various historical processes (de Certeau 2010: 24; Tsing 2005: 81). For west Namibia, such diminutions have been associated with the governance and truth regimes effected by colonialism and apartheid. They have been structured more recently through marketreliant approaches to the conservation of wildlife and 'wilderness' landscapes, involving access by global tourism markets and a programmatic national approach to Community-Based Natural Resources Management (CBNRM). ${ }^{6}$

The people I have been working with in this context desire to be named in written material that thereby arises. In this specific case, they are Ruben Saunaeib Sanib, a formerly renowned hunter of a $\|$ Khao-a Dama family grouping associated with the mountainous areas of west Namibia, and Sophia Obi |Awises, a \|Ubun lady whose lineage split at an unknown time in the past from $\neq$ Aonin/Topnaar Nama living in the Walvis Bay area of the !Kuiseb River to the south of this area. ${ }^{7}$ Both Ruben and Sophia, amongst numerous others, grew up and lived in a broad area of land cleared of people living there some decades ago. These clearances were enacted for several reasons: to periodically create a livestock-free zone north of the veterinary fence that dissects Namibia so as to control the movement of animals from communal areas in the north to settler commercial farming areas in the south (Miescher 2012); through a short-lived extension of 'Game Reserve No. 2' (better known now as Etosha National Park, see Figure 1) from 1958 to 1970, when its western boundary was moved to the coast ${ }^{8}$ (Tinley 1971: 10); in the 1950s to make relief grazing available to Afrikaans livestock farmers under Namibia's South African administration (Kambatuku 1996); and, in the 1970s, to consolidate the area as a wildlife hunting, and then tourism, concession known as Palmwag - often described today as a 'pristine wilderness' (e.g. Felton 2011).

Going into what is now the Palmwag Concession landscape with Ruben, Sophia and others in the course of a number of journeys throughout 2014 and 2015, has meant observing certain protocols, in

\footnotetext{
${ }^{5}$ See http://www.nationaltrust.org.uk/glastonbury-tor/ last accessed 29 October 2015.

${ }^{6}$ On CBRNM in the study area see Sullivan (1999, 2002, 2003), Pellis (2011) and Pellis et al. (2015), as well as program information at http://www.nacso.org.na/what_is_cbnrm.php (last accessed 3 February 2016). An overview of some of the structural circumstances shaping and being shaped by west Namibian contexts is available in Sullivan et al. (2016).

${ }^{7}$ ||Khao-a and ||Ubun are identifying terms for interconnected and overlapping land and lineage groupings (!haoti) within the broader Khoe-speaking cultural designations of Dama(ra)/キNūkhoen and Nama (see also Sullivan and Hannis 2016).

${ }^{8}$ Prior to the establishment of the Skeleton Coast National Park in 1971.
} 
particular around a practice called tse-khom. ${ }^{9}$ This involves talking to the spirits of ancestors buried at numerous places throughout the Concession and beyond, as well as to anonymous 'spirits of the dead' (Schmidt 2014a: 135) and sometimes to a more broadly referenced ancestor-hero known as Haiseb. The latter is considered to have been a real person who lived in the past and who is associated with doing wonderful and clever things, and with whom large cairns found in the dryland environments extending from the Cape to the Kunene River are associated (also see Schmidt 2011, 2014a, 2014b; Sullivan and Hannis 2016: 12-14). Tsekhom introduces travellers to the kai khoen, i.e. 'big or old people', whose presences now as ancestral agencies are requested to act so as to open the road in order that travellers can see the best way to go. They are asked to mediate the activities of potentially dangerous animals such as lions, viewed very much as other ensouled beings who assert their own agencies and intentionality, and for guidance regarding the most appropriate ways to do things. In tse-khom, the ancestors are souls whose ontological reality means they can assert various kinds of agency in the present, sometimes over other kinds of agency, such as that of animals. And I have to say that the more I travelled in the company of Ruben, Sophia and others, and the more we practised tsekhom, the more it indeed appeared as though our journey was being influenced by the agency of the ancestors.

One manifestation of this influence occurred at a permanent spring called Kai-as, a former dwelling place mentioned in several oral histories recorded with people who now live on the periphery of the Palmwag concession ${ }^{10}$ (Figure 1). Kai-as is now deep in the Palmwag tourism concession area, but it is also a place where, possibly for generations, people planted gardens, herded livestock and hunted and gathered foods and other useful things. It was a place where groups of people dispersed throughout the broader landscape would meet in the rainy season, to socialise and to play their arus and Igais: their healing dances and their songs 'sung for happiness' that celebrate everyday experiences with various beyond-human others. When Ruben and Sophia talked about this time they spoke of it as 'when their hearts were happy.' Returning to this place in the present was emotional, given the multiple losses their eviction had caused, not least the loss of being able to provide company for their ancestors, including a known ancestor in Ruben's lineage who is buried at a noticeable grave at Kai-as.

Indeed, on the occasion of this journey to Kai-as, an incident occurred regarding the grave of Ruben Sanib's ancestor that drew to my mind the book The mists of Avalon with which I open this article. My longstanding companion in field research, a \|Khao-a Dama woman called Welhemina Suro Ganuses, was amazed to encounter this grave at Kai-as. She explained to me that she had travelled the track here several times previously from the opposite direction in the course of her normal work for the Namibian conservation NGO Save the Rhino Trust ${ }^{11}$. On these occasions the grave would be clearly visible right in front of the vehicle, but she had never before seen the grave. Disruption of prior livelihoods associated with this landscape has led to poor knowledge amongst younger generations of the detail of ancestral connections with places here. On her previous visits to the area she had thus not known to do tse-khom at this place (although this is a practice with which she is familiar). For Suro, then, this explained why the ancestors had not previously elected to reveal themselves to her. As with knowing the right words to be able to open the mists to that other Avalon, for her what had enabled us to be able to see this grave on this journey was that we had been practicing tse-khom and talking well to the kai khoen.

\footnotetext{
${ }^{9}$ For consistency, I tend to be led by spellings used by Welhemina Suro Ganuses, with whom I have worked on transcriptions, translations and interpretations of $\neq$ Nūkhoen material since the mid-1990s. Detailed orthography is available in Haacke and Eiseb (1999, 2002).

${ }^{10}$ For example, in multiple interactions with Ruben Saunaeib Sanib, Sophia Obi |Awises and Michael Ganaseb in 2014 and 2015, in interview with Franz \|Hoëb (060414) and with Franz \|Hoëb and Noag Ganaseb in November 2015.

${ }^{11}$ http://www.savetherhinotrust.org/
} 


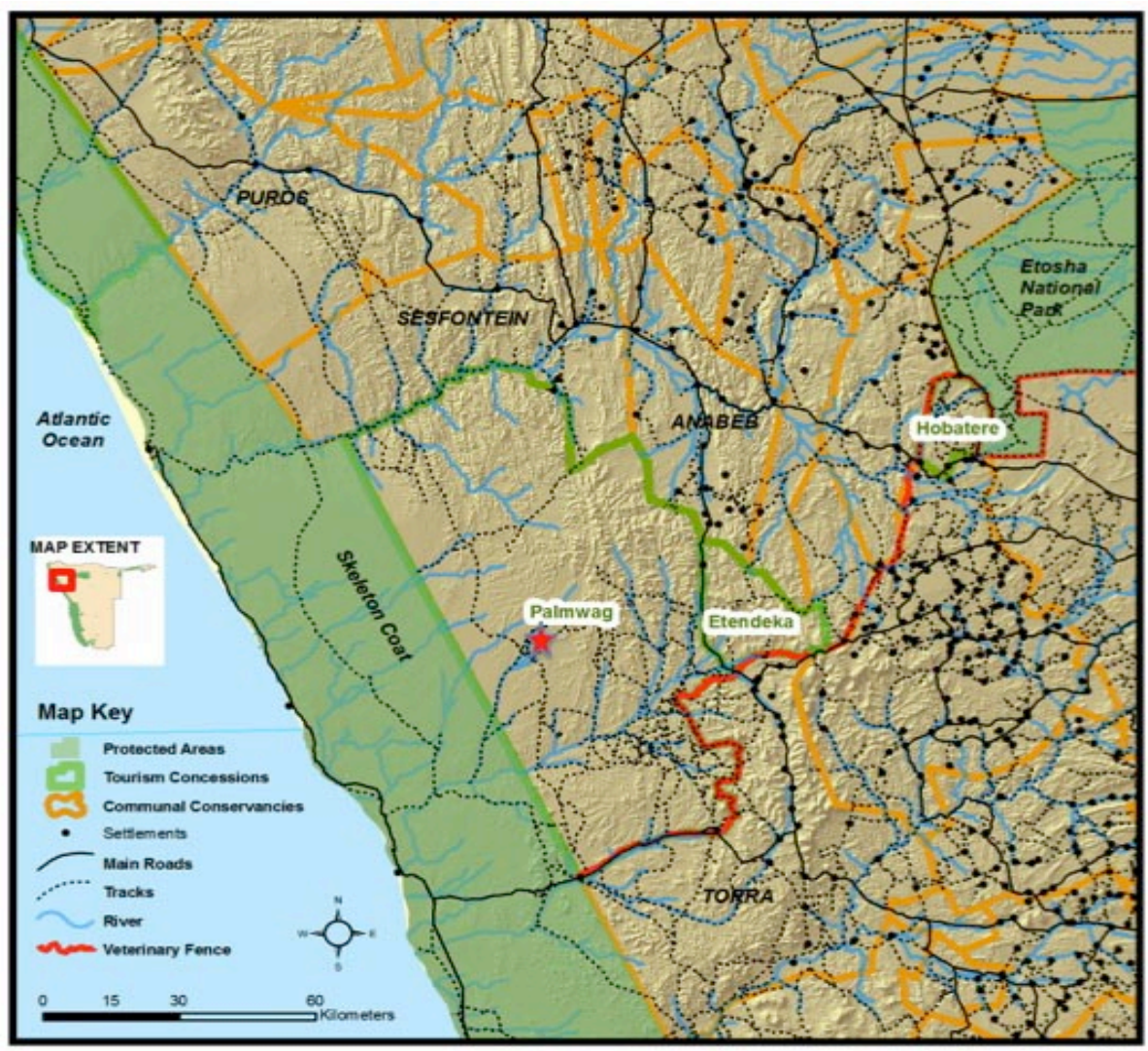

Figure 1: Map of study area showing the boundaries of the Palmwag tourism concession, with the red star close to the centre of the map indicating the rough location of the former settlement of Kai-as. Source: Map generated by Jeff Muntifering, 5 March 2016.

This incident is amongst numerous stories and experiences confirming the agency of ancestors and their ability to intervene in the agency of other entities. Other nonhuman agency-enacting entities in this context include animals as ensouled beings that see us and act in relation to this (cf. Kohn 2013), and the personified, supernatural force behind the phenomenon of rain - known as |nanus - that asserts agency in selecting those humans who become healers (Low 2008; Sullivan and Hannis 2016). Indeed, the affirmation of agency and intentionality in multiple entities and selves beyond-the-human might be considered as key to KhoeSan and other 'animist' perspectives on 'reality', through which agency, shaped by the diverse form, materiality and perceptual capacities of actors, is considered to be present everywhere, requiring constant attention and attunement in choices made by humans (Brightman et al. 2013; Descola 2013; Harvey 2005; Kohn 2013; Sullivan 2010, 2013a; Sullivan and Low 2014). This perspective on differentiated agency and intentionality distinguishes 'animism' from the vital materialism privileged in the 'machinic assemblages' of Deleuze and Guattari (1987(1980)), later reformulated as actor network theory (Latour 2007), and latterly expressed as an invigorated awareness of the organisational and ethical imperatives asserted by specific materialities (Bennett 2010; Hecht 2012; Jackson 2013). Animist perspectives instead emphasise the ethical perspectives and practices that may arise when people live and act as if diverse other kinds of being can see and in some way represent 'us' (Kohn 2013: 1). In structuring understandings of the nature of being, this perspective assumes that all activity by agents who can be animals, components of weather, plants, spiritbeings, ancestors and so on, is simultaneously imbued with a moral, if relative and frequently ambiguous, 
dimension (Ingold 2000), requiring ongoing awareness, participation and adjustment in relation to the actions of all these acting others (Deleuze and Guattari 1987(1980): 258, 266-267).

Of course, we aspiring moderns, with our calculative rationality (Weber 2010(1930)) and our positivist modes of verification (Latour 2013) know that these spirited and ensouled agencies do not possibly exist. Except that if there is one thing to be learned from the will to make the familiar strange and the exotic familiar - as encouraged by what might be considered the first principle of social anthropology (cf. Malinowski 1922) - it is this: that when people live as if something is real - through repeated and shared invocations, affirmations and practices - then this reality does indeed tend to be(come) real, not only in the realm of symbolic representation regarding the 'reality' shared by groups of people, but perhaps also more literally in the ways that the world is understood and encountered to be (I return to this point later in the article). As such there is perhaps a certain slippage between 'folk and formal' (Sullivan 1999) classificatory correspondences, as detailed in work by ethnobiologists such as Brent Berlin (Berlin 2014(1992)), and ontological phenomena regarding the foundational nature of being which 'overflow', and thus cannot be 'shoehorned' into, these classificatory correspondences. It is these latter phenomena that might be said to constitute foundational differences in assumptions and experiences of the types of entities that can be said to exist so as to make up the nature of the reality that is experienced, participated in and 'managed.' Or, as philosopher Rupert Read (2012: ix, also 20-22) writes, "'Incommensurabilism' is not tantamount to Relativism; it is rather about understanding the depth of the difference between the two cultures being compared" so as to be able to take such differences seriously, instead of seeking to bring what is different into what is conceptually familiar (also see discussion in Blaser 2013). It is this invocation of differences in how 'the real' is understood to be, as well as the ethical shaping that this may effect, that makes 'ontology' relevant for political ecology understandings of the consolidations and impacts of particular environment and development policies.

In what follows I move next to a consideration of what I am understanding by the term 'ontology', followed by a section outlining some views on why ontology matters for political ecology conceptualisations of relationships with natures-beyond-the-human. I then engage with the ontological dimensions that both underscore, and are amplified by, contemporary 'green economy' approaches for suturing economic growth with the management of urgent environmental crises, focusing on a constellation of 'aggregate rules', 'offsetting' and 'no net loss', and 'decoupling.' I close with a brief conclusion affirming the relevance of ontological considerations for improved political ecology sensitivity to diversity in cultural understandings of the nature of being.

\section{What's ontology?}

Ontology means literally the study of being, i.e. of what can be said to exist. It is "that branch of metaphysics dealing with the ultimate nature of reality", that nonetheless is approached differently and concerned with different kinds of existents depending on "culture" (Smith 1981: 1). Scholarly curiosity has long been piqued by the existence of plural ontologies, i.e. of diverse ways of framing and understanding the nature of reality, and of acting in relation to the assumptions that thus arise. Herodotus' (1998(ca. 440 BCE)) Histories of the fifth century BCE, with its detailed discourses on the understandings and practices of diverse cultures encountered as he travelled through north Africa and the lands of the eastern Mediterranean, clarifies as much.

More recently the philosopher Wittgenstein in his later work suggests that meaning regarding the nature of being is not fixed to a foundational and singular ontology, but instead arises, and is both confirmed and contested, through language games deployed through activities in multiple, overlapping and negotiated social contexts (Johnson 2008, discussing Wittgenstein 2001(1953); also Read 2012, and pers. comm.). As such, "a community's values are intimately bound with the capacities the community has for talking about and framing the world" (Johnson 2008: 14). Since "reality has no [necessary] compulsion to restrict itself to being in itself the kind of thing that we can describe" (Johnson 2008: 14), this opens the way for the existence of multiple ontologies (i.e. multiple ways of understanding and communicating the nature of being). Indeed, even the 'hardest' of sciences, namely physics, makes varied and contested postulates regarding the foundational nature of being and the methods through which this can be known. The radical historical shift 
from Newtonian mechanism to quantum indeterminacy within the last 100 years, and the current variety of views regarding underlying universal phenomena (particles, strings, plasma, etc.), illustrate this diversity. It was the existence of such shifting ontological incommensurabilities and transformations that formed the basis of Thomas Kuhn's (1970(1962)) historical analysis of continuities and discontinuities in scientific knowledgebuilding. Around the same time, Foucault's (1970) groundbreaking account of the variously stable and shifting conditions of truth in the life sciences similarly affirmed both situated stability and plurality in discourses and assumptions regarding the nature of existence. Foucault's term episteme - the self-reinforcing grid of assumed or a priori knowledge of reality that infuses and permits sense-making to occur in all discursive interactions flowing from and reinforcing an historical period or epoch - cannot help but also be imbricated with specific ontological dimensions (Sullivan 2006: 109).

In the academic fields of environmental anthropology and political ecology, a move towards ontological considerations has intensified as researchers have dug more deeply into divergences regarding the assumed nature of reality, as indicated by differences in how environmental phenomena are framed and thereby known culturally. Concentrating in the 1990s amidst the background of the so-called 'science wars' of that decade (see especially Sokal and Bricmont 1999), detailed research in these domains demonstrated that a range of 'received wisdoms' regarding environmental phenomena, in response to which development policies were being designed, could be understood instead as knowledge constructions built discursively with significant power-effects in terms of access to land and 'resources' (for African contexts see, for example, Benjaminsen 1993; Fairhead and Leach 1996; Homewood and Rodgers 1987; Leach and Mearns 1996; Richards 1985; Sullivan 2000). These studies demonstrated that powerful national and international discourses regarding 'the environment', which tended to demote and even demonise the use and value practices of local people in the contexts researched, could be destabilised and deconstructed by bringing varied sources of data to bear on their key assertions. As such, these researchers assumed a critical realist approach to the acquisition of knowledge regarding the nature of environmental change(s) (Fairhead and Leach 1996; Forsyth 2001; Sullivan 2000). They affirmed the existence of an environment 'out there' that can be known through empirical research methodologies; whilst simultaneously asserting that the deployment of methods and data to produce policy-relevant environmental knowledge also reflected the 'regimes of truth' shaping prominent views of the world and supporting associated powerful interests (cf. Foucault 1970, 1980, 1982). Amongst environmental anthropologists, geographers and political scientists alike, this Foucaultianinspired orientation towards empirical understanding of the constructed nature of dominant environmental knowledges and discourses has been key to the emergence of the field of 'political ecology' (see, for example, Adger et al. 2001; Bryant and Bailey 1997; Forsyth 2003; Robbins et al. 2010; Stott and Sullivan 2000).

Diversity in affirmed knowledges regarding environmental phenomena, coupled with perspectives on the social and political dimensions of the construction of these knowledges, mean that totalising signifiers such as 'nature', 'the environment', and 'degradation' of these, denote things that 'in [both] discourse and practice [are] socially made, not ontologically given' (Castree 2003: 205). What can be added to this is that the different natures that are socially made in particular contexts are also understood as having ontological or essential reality; or, at least, that the specific natures of their form and existence is socially agreed upon (in these contexts). It is this diversely assumed and agreed upon ontological reality that makes entities knowable to their socio-culturally connected interlocuters; even if accompanying knowledges and certainties might also be 'unpacked', 'deconstructed' and 'problematized', i.e. shown to be socially, politically and historically particular, from different perspectives that are themselves also situated (Foucault 1970; Chakrabarty 2000; Sullivan 2016a).

Ontological assumptions and praxis, then, denote what entities can exist, into what categories they can be sorted, and by what practices and methods they can be known (i.e. epistemology), for participants in a social grouping sharing and negotiating these assumptions. Knowledges and performative practices are thereby both based on, and recursively amplify, specific ontological 'realities', so as to affirm a 'multiplicity of forms of existence enacted in concrete practices' (Holbraad et al. 2014: online). In recent years, a consolidated 'ontological turn' in the social sciences and humanities more broadly has emphasised diversity in how cultures globally may know the nature of the natures they both utilise and with which they co-exist (Smith 1981). Building on earlier work by anthropologists such as Hallowell (1960), a cross-cultural perspective 
increasingly affirms that cultural and historical differences create the possibility for plural cultural ontologies (Descola 2013), or 'philosophies of being' as Tsing puts it (2014: 12). Acknowledging the possibility of plural ontologies permits productive engagements with diversity in 'experiences and understandings of the nature of being itself', even to the extent of proposing an 'anthropology of ontology' or 'an ontology-centred anthropology' (Scott 2013: 859, 868 and references therein).

Importantly, from anthropological as well as postcolonial perspectives, modern and post-Cartesian assumptions regarding how nature is constituted and can be known, whilst universalising, may be understood to in fact be highly particular (Chakrabarty 2000). They are embedded in, and have been made possible by, particular cultural and historical contexts that do not necessarily translate well into diverse 'nonmodern' cultural experiences (Descola 2013; Kohn 2013; Viveiros de Castro 2004). As Mol (2002: 6, emphasis in original) writes "ontology is not given in the order of things, [...] instead, ontologies are brought into being, sustained and allowed to wither away in common, day-to-day, sociomaterial practices." Ontologies (as philosophies of being) are made through interactions between human and other-than-human agencies, as well as shared and varied communications regarding these interactions and the dynamic and hybrid assemblages that thereby arise (Blaser 2013; Descola 2013; Sullivan 2016b). Ontology as a way of 'worlding' - i.e. 'of enacting a reality' (Blaser 2013: 23) - suggests the parallel existence of different ways of understanding how reality is constructed (ontology), how the world and its entities can be known (epistemology), and what constitutes appropriate and ethical praxes in relation to these entities (ethics). This triad might be seen as both significantly mutually-reinforcing for groups of people in specific temporal moments, whilst simultaneously inflected by the ambiguity, ambivalence, internal difference and 'gaps' that make possible creativity, contestation and change (Foucault 1970).

This perspective, however, is not uncontroversial (see vehement critiques in Graeber 2015, and Vigh and Sausdal 2014). Graeber maintains that it is more appropriate to privilege a "realist ontology" accompanied by a "theoretical relativism": thus celebrating "incommensurable theoretical perspectives on a reality that ... can never be entirely encompassed by any of them - for the very reason that it is real" (2015: 31, drawing on critical realist philosopher Roy Bhaskar). It remains difficult, however, to see exactly how this differs from an embrace of plurality in the ways that people may understand the nature of how the world is constituted, and thereby demonstrate diversity in both meaning-making and actions in relation to this plurality of natures. Indeed, Graeber's strategy in itself cannot escape the necessity of naming and framing what a realist ontology might be based on, practices which themselves cannot escape being socially-situated and thus particular in various ways (cf. Chakrabarty 2000). Graeber himself presents examples in his article that rely on the existence of entities that different ontological regimes - as discourses concerning the nature of being might simultaneously claim as facts and as impossibilities: viz. the existence of spirit beings, known as entities with "their own autonomous agency, moods, whims, even personalities" in Malagasy truth regimes (Graeber 2015: 29), compared with the impossibility of their existence in universalising modern perspectives on the nature of being and how this can be known (Chakrabarty 2000). As such, Graeber seems to affirm that plural and culturally-inflected ontologies exist in the world - consolidated through practice, and associated dynamically with the (re)production of varied effects - whilst also diminishing to some extent the diversely emic meanings through which this plurality is generated, affirmed and known. ${ }^{12}$

In this article I (too) write from a perspective that, in a formal sense, ontology is a mode of enquiry that asks questions regarding the nature of being so as to make assertions regarding the nature of reality and how this can be legitimately known. At the same time, I affirm that what becomes known ontologically arises through social processes (shared language games, the production of texts, methods of enquiry and associated institutions) that create conditions for how the 'Real' that resists symbolisation (to invoke Lacan, see Fletcher 2013, 2014a) may be known (Foucault 1970). This might be summed up in a well-known quote by cultural theorist and activist Susan Sontag (1963: 1) that "[t]he truth is always something that is told, not something that is known. If there were no speaking or writing, there would be no truth about anything. There would only be what is." For me, then, a critical realist perspective (i.e. that assumes a world exists independently of the

\footnotetext{
${ }^{12}$ On recourse to Cartesian-based truth claims in anthropology and a corresponding denial of alterity, also see Scott (2013: 863).
} 
observer) accepts that this world can be differently and diversely known - this diversity arising from culturally- and historically-inflected negotiations and assumptions regarding the ways that the world is made, so as indeed to differently shape ontological understanding (Forsyth 2001; Sullivan 2000). Political ecology reflects this endeavour to engage with the political construction of what is framed and known to be 'ecological' in the contemporary moment (Forsyth 2001). My desire here is to inflect this further still through drawing out some significances of how ontological plurality may shape the socionatural 'reals' that are thereby known, privileged and politicised (also see Blaser 2013).

To sum up, at this point, it seems that there are a range of acknowledged 'reals' here that are in tension with each other. These include:

1. The diverse 'reals' woven together through culturally-inflected invocations and embodied practices that are based on ontological assumptions regarding the nature of being and how this can be known, and that imply corresponding assumptions regarding who 'we' are as agents acting in the world, as well as what entities might be included in the sphere of agency;

2. a hint of the Lacanian 'Real', commonly framed as the state of nature from which we have been forever severed by our entrance into language, but that may puncture the fantasies woven together through the human talent for complex symbolic representation in ways that prompt crisis, change and adjustment (as detailed in Fletcher 2013, 2014a);

3. and an entwining of both the above such that the existential nature of the underlying Real may also be the ontological object of culturally-inflected enquiry and assumption, i.e. 'it' may be understood and known differently, in diverse cultural and historical settings as well as in relation to individual circumstances and moments (Sullivan 2016a).

I am perhaps better placed now to consider why ontology matters for political ecology understandings of relationships with natures-beyond-the-human, as well as to explore some particular ontological assumptions that seem to inform neoliberal green economy environmental policy-making.

\section{Why ontology matters for relationships with natures-beyond-the-human}

Ontology matters because consolidated assumptions regarding the nature of categories of being in the world shape human action in the world, and thus have ethical, including ecoethical, effects (Sullivan 2013a). Indeed, this is a core dimension of the field of 'political ecology': namely to critically analyse the making and structuring effects of environmental knowledges in the world, in the course of also understanding and intervening in the social and environmental justice implications of these knowledges and the uses to which they are put (e.g. Jarosz 2004; Sullivan 2000). In embracing this normative dimension, for my part, then, I am interested in cultural ontologies that seem to me to also correspond with what I perceive to be 'better', i.e. more accommodating, ways of living with diverse kinds of being. 'Better', for me, means living in ways that encourage equitability and moral considerability ${ }^{13}$ between humans, as well as with the different kinds of agencies that constitute other-than-human beings. This is a position that accepts that difference makes a difference (Kohn 2013, after Gregory Bateson), whilst at the same time acknowledging that we humans simultaneously exist in a continuum of connections and interactions with different-kinds-of-beings: from sharing DNA; to sharing capacities for biosemiotic communication through "nonsymbolic representational modalities [that] pervade the living world" (Kohn 2013: 8; also Wheeler 2006); to sharing soul (as my Damara companions would affirm) (Sullivan and Hannis 2016); and to sharing a telos of embodied enthusiasm towards flourishing that seeks to exceed the suck of entropy into which the materiality of bodies inevitably sinks (Abram 2010: 48; Massumi 2014).

An ontological problem for Euro-American reality is that we find ourselves living in the shadow of two thousand years of hierarchical value-ordering in western thought which has affirmed that only humans,

\footnotetext{
${ }^{13}$ Moral considerability: being worthy of moral consideration.
} 
and often only some humans, possess intelligence and mind (see Figure 2; also, discussed in Sullivan 2016a, b). At the other end of the hierarchy plants, for example, are viewed merely as 'vegetables': dispossessed of the capacities of movement, perception, communication, and immanently-directed telos, and thus usefully backgrounded as existing only for the instrumental ends of humans (as substantively critiqued in Hall 2011; Head et al. 2015; Marder 2013). In this hierarchical ontology only humans are worthy of moral consideration, since only we are ranked as possessing capacities such as communication, purpose and subjectivity.

The ontological denial of these faculties in other kinds of being, permits the doing of harm without recognition that harm is being done. Although perhaps it is more complex than this, in that denial tends to manifest more as disavowal: as the simultaneous acknowledgement of harms caused, accompanied by a strategy - an apparent solution - to seemingly mitigate this harm. I will return to this point later, but an example of this, and of the pathology that such 'solutions' can embody, comes from the post-Cartesian vivisectionists. As I have discussed elsewhere (Sullivan 2013a, 2016a), whilst operating in a Cartesian mode (i.e. construing animals as soulless automata (Descartes 1968(1637): 75-76), these 'life scientists' would also sever the vocal cords of their experimental subjects so that they would not be able to hear their animal cries of pain (Evernden 1985: 16-17; Hornborg 2006: 24). Through this apparent 'solution' these actors split their acknowledgment of the communicative and experiential capacities of animals from their denial of this possibility, so as to literally make the animals subject to their experiments into mute objects.

But the Platonic, Aristotelian and Cartesian ways of constructing orders of value and moral considerability in 'the West' are particular (also see Sullivan 2013a, 2016a and b). They are not shared by many people living in the world today (see, for example, the contributions in the volumes edited by Descola and Pálsson (1996), Dransart (2013) and Green (2013)), and they have arisen historically as a rupture from prior ontologies that may have been more inclusive in terms of moral considerability (Cohen 1986). This is even as the necessity of doing harm to others in the course of living is recognised, through which others are knowingly transformed from communicative subjects into the objects of food and other usable things - just as nonhuman others such as lions, for example, might be perceived as similarly objectifying 'us' so as to turn human persons into objects of prey (Kohn 2013). The suggestion here is that living in an expanded sphere of moral considerability - wherein nonhuman others are ontologically known as possessing different capacities for agency, the will to flourish, and the ability to also see and represent us (see, for example, Århem 1996) acts as one social check amongst others against the disembedding from, and ruthless instrumentalization of, natures-beyond-the-human that has been so defining of capitalist market economy (cf. Clastres 1990(1974); Polanyi 2001(1944)).

Locating agency in beings-beyond-the-human, then, might be one route towards bringing nonhuman others more clearly into presence as distinctive actors and interpretants alongside us in the rich, relational 'ecology of selves' we live with(in). Following Kohn, living as if the ways that other kinds-of-being represent, and communicate with, us matters, also beckons towards an opening up of the philosophical concept of flourishing so as to include different kinds of selves beyond-the-human as beings who also, in their own ways, are reaching for 'a good life' (Hannis 2015). 'Flourishing' is a central concept in Haraway's (2008) When species meet and Kohn's (2013) How forests think. But it is also a privileged term in the philosophical domain of virtue ethics - the branch of philosophy connected with the classical Greeks that considers what it means, and what is required, to live 'a good life' (for a broader discussion of virtue ethics see Hannis (2016) and references therein). The vegetal, generative term 'flourishing' (Marder 2013) is used increasingly as a translation of the Greek term eudaimonia, associated with the goddess of happiness and prosperity, and comprised of terms for 'good' or 'harmony' combined with 'spirit' or 'soul.' A life lived well and harmoniously was thus often framed in terms of 'a good of the soul - not a material or bodily good such as wealth or political power' (Cook 2013: 21). 


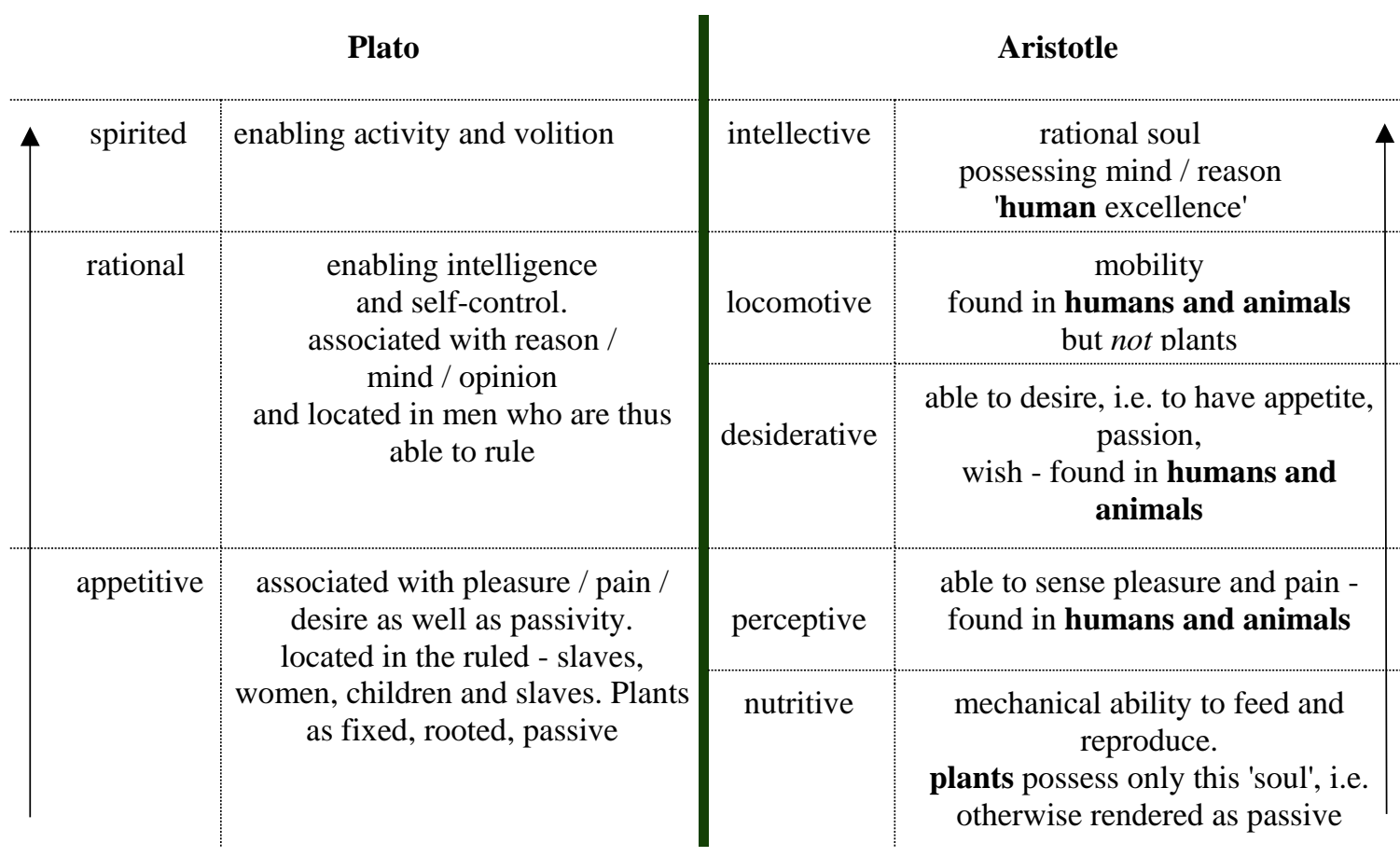

Figure 2: Plato's and Aristotle's ontological value hierarchies of faculties of soul. Source: based on Hall, M. Plants as persons: a philosophical botany. New York: SUNY Press, pp19-26; after Plumwood, V. Feminism and the mastery of nature. London: Routledge.

As noted above, however, Cartesian ontology strips living creatures of the presence of soul, so as to make humans exceptional in these terms whilst creating pacified objects and automata of nonhuman others (see Descartes 2015(1649). This is a move that is both a way of knowing and of making the world, in the sense that animals and other entities that become conceived as soulless objects are thereby also treated as such (see discussion in Baird Callicott 2013: 112). It is also a move that for my Damara companions in west Namibia - who are very familiar with notions of soul as well as with the realities of living with diverse nonhuman others, some of whom may eat people - consider derisory: as in, of course animals (from lions to harvester ants) are animated by the presence of soul.

This leads me to two observations with which to close this section. The first, and whilst acknowledging the danger of idealisation, romanticism and essentialism here (see discussion in Sullivan 2006), is that I notice the following confluence of circumstances: that when people know other-kinds-of being as 1) animated with soul; 2) as communicative, albeit in biosemiotic registers that are different to the symbolic representation so defining of human (after Kohn 2013); and 3) as asserting distinctive, hybrid and lively capacities of agency and purpose that exceed their instrumentalization for human economic ends, there often seems to be an emplaced correspondence between these ways of knowing and the actual flourishing of environmental parameters, especially of 'biodiversity' (cf. Gorenflo et al. 2012). As Viveiros de Castro (2013: 35) writes for a different context, 'the indigenous areas of the Amazon are the least deforested areas of the whole region.'

The second thing I notice is that groups of people desiring either to continue with these apparently 'green' ways of knowing and living, or to establish them within modern, industrialised contexts, seem to do so largely in a state of conscious antagonism, resistance and banishment vis à vis the strongly hierarchical and instrumental powers associated with the modern state and capitalised markets (cf. Foucault 2011(1983-1984): 186). A current example is the significantly reduced acknowledgement of indigenous concerns and rights from the adopted text of the Paris agreement arising from the 2015 United Nations Conference of Parties for the 
Framework Convention on Climate Change. ${ }^{14}$ These then become struggles against what Foucault (1982) calls the "laws of truth" imposed on others who become "subject to someone else by control and dependence." 'Green economy' proposals and policies for neoliberal market exchanges to solve issues of global environmental degradation whilst maintaining economic growth, can be seen as a route through which such 'control and dependence' imposes 'laws of truth' on resistant human and nonhuman others, as considered in the next section.

\section{Ontology and 'the green economy'}

The section above discussed how ontology denotes approaches to the nature of being, asserting that ontological assumptions are diverse, shaping how 'the world' can be known legitimately (epistemology), as well as the conception of appropriate actions in the world (ethics). In this section I consider some of the ontological assumptions infusing so-called green economy responses to accelerating anthropogenic alterations of ecosystems and the atmosphere (Steffen et al. 2015). The 'green economy' here refers in particular to an emphasis on internalising environmental externalities through pricing mechanisms, so as to approach problems of environmental degradation mostly as market failures that can be solved through market instruments (discussed further in Pawliczek and Sullivan 2011; Sullivan and Hannis 2015). Such proposals of necessity frame (Lakoff 2010), calculate and perform (Callon 2006) the so-called 'natural environment' as a formally economic entity or set of entities, ontologically flattening diverse natures into "frameworks of undifferentiated 'orderings' yoked to global chains of commodity production" (Joronen 2013: 631). This process is consolidating a metaphorical language of 'ecosystem services' and 'natural capital' in environmental management (discussed further in Sullivan 2009, 2013b, 2014 and references therein), as well as the rapid emergence of calculative technologies that rely on numerical presentations of nature aspects so as to support the marketized realities of offsetting, payments for ecosystem services and so on. I am of course bracketing out a much older 'green economics' tradition, that advocates strategies to re-embed, i.e. to 'couple', economic activity with emplaced ecologies (see, for example, Scott Cato 2012).

Here I focus on three key elements in the consolidating neoliberal 'green economy' 'toolkit' to consider their ontological assumptions and amplifications. These elements are:

1. Orderings of entities at national and global scales in terms of 'aggregate rules';

2. the offsetting of calculated environmental elements considered to compose these aggregates as a key method for managing environmental harm and health; and

3. the valediction of a discourse of 'decoupling' economic growth from environmental parameters as both possible and necessary in order to create and sustain 'green growth.'

\section{Aggregate rules in generating a green economy}

Writing this article in the immediate aftermath of the United Nation's Framework Convention on Climate Change $21^{\text {st }}$ Conference of Parties (COP21) it was noticeable that notions of 'zero-carbon' and 'net carbon neutrality' were being reinforced as critical for climate change management (see review in Reyes

\footnotetext{
${ }^{14}$ As demonstrated in the various iterations of the agreement. The draft agreement on $5^{\text {th }}$ December 2015 included the following square-bracketed (i.e. contested) wording for Article 2.2: "[This Agreement shall be implemented on the basis of equity and science, and in accordance with the principle of equity and common but differentiated responsibilities and respective capabilities, in the light of different national circumstances, and on the basis of respect for human rights and the promotion of gender equality [and the right of peoples under occupation].]" (http://indigenousrising.org/wpcontent/uploads/2015/12/draft_paris_agreement_5dec15.pdf, accessed 16 December 2015). Article 2.2. in the final agreement of 12 December 2015 says instead: "This Agreement will be implemented to reflect equity and the principle of common but differentiated responsibilities and respective capabilities, in the light of different national circumstances" (http://unfccc.int/documentation/documents/advanced_search/items/6911.php?priref=600008831, accessed 16 December 2015). Indigenous peoples are dismayed and furious at the removal of language acknowledging their specific rights as "peoples under occupation" (Lukacs 2015), which is how many such peoples are experiencing both the realities of fossil fuel exploration and extraction, and carbon accounting of forests so as to mitigate the products of such extraction. COP21 was thus accompanied by a number of protests and interventions by peoples who identify as 'indigenous.'
} 
2015). These notions indicate a consolidation of aggregate thinking in the international environmental policy arena. This consolidation proposes management around measurable aggregate levels that should be maintained, and thereby paves the way for substitutabilities between the materialities calculated as constituting this aggregate. In carbon management, fossil fuels can thus continue to be burned since their emissions can be offset through the acquisition of carbon credits representing carbon gains stored elsewhere. Such exchanges seem set to rely increasingly on assumptions and calculations of equivalence between industrial emissions and organically-stored carbon biomass, so as to achieve a "balance between anthropogenic emissions by sources and removals by sinks of greenhouse gases" (UNFCCC Paris Agreement 2015, Article 4.1). It may also infer carbon equivalence between plantation forests and old-growth forests, leading to conversion of the latter into the former, as can occur, for example, through the expansion of biofuel plantations.

In these cases, calculations that enact different entities in terms of the element of carbon only, are coupled with aggregate carbon budgets positing ontological equivalence between these entities on the basis of their carbon composition. Such calculative and ontological moves in turn stand to permit the sustenance of carbon emissions, the accumulation of newly commodified and exchangeable carbon values, and an entrenching of a fossil fuel(ed) economy frequently accompanied by the discounting of forest-inhabiting peoples with different views and ontologies regarding how their lands should best be managed (Cavanagh and Benjaminsen 2014; Dunlap and Fairhead 2014; Sullivan 2015).

Time will tell how the 2015 UNFCCC Paris Agreement plays out. Research on carbon markets to date, however, is ambiguous regarding the ability of such markets to do what proponents say they will, i.e. to reduce aggregate carbon levels through trading emissions in one place with the purchase of credits tied to carbon reductions and/or storage somewhere else (Lohmann 2009). A recent in-depth review of carbon credits awarded and traded under the Kyoto Protocol's Joint Implementation (JI) mechanisms, for example, details how revenues from credits have created "perverse incentives to increase production or generation of waste gases as a means to increase credit revenues from waste gas abatement" (Schneider and Kollmuss 2015: 1061). The authors argue that in this case a market in carbon credits under JI may have increased emissions by about 600 million tonnes, and that emissions reductions in many cases may have happened without the associated international carbon credit purchases, meaning that such trades do not meet their stated purpose of generating carbon emissions reductions that are additional to those that would have occurred anyway, i.e. in the absence of such trades. Of course, given the emphasis on competitive rent-seeking in neoliberal markets it is unsurprising that such perversities should arise. Markets in themselves cannot generate ethical or environmental(ist) choices and behaviour (cf. Sullivan 2010), and outcomes not predicted in the design of their incentive structures are arguably inevitable.

Nonetheless, moves to (re)frame 'nature' in terms of the new 'nature-whole' (cf. Asdal 2008) of 'natural capital' are encouraging similar aggregate models. The UK government's Natural Capital Committee, led by economist Dieter Helm, advocates an 'aggregate natural capital rule' which states that it is maintenance of measured 'natural capital' in the aggregate that counts. A key intention of creating national natural capital accounts, as promoted, for example, by the World Bank under its WAVES (Wealth Accounting and the Valuation of Ecosystem Services) programme, ${ }^{15}$ is thus to calculate stocks of nature-as-natural-capital (i.e. overall) in such a way as to support maintenance of measured elements above relevant thresholds, whilst permitting substitutability between the calculated values for different types of capital, as well as between different types of 'natural capital' (at the broadest level between 'non-renewable' and 'renewable' natural capitals) (see Helm 2015 and discussion in Sullivan in press). The UK's Natural Capital Committee promotion of an aggregate natural capital rule thus paves the way for losses and gains to be exchanged between different 'capitals', so that 'no net loss' allegedly occurs in aggregate (Helm 2014; Mace 2014).

Maier (2013: 34) frames such aggregating approaches as based on the "peculiar brand of marketframed, preference-based consequentialism" (i.e. ends-oriented choices) adhered to in neoclassical economics. He highlights the tendency of such aggregating approaches to discount particularities by advocating substitutabilities between them, thereby indicating that from an ecological perspective an "aggregate natural

\footnotetext{
${ }^{15}$ See http://www.wavespartnership.org/en
} 
capital rule" seems additionally "peculiar." Indeed, an ecological ontology might instead be alert to various dimensions that would engender caution vis à vis an aggregate rule sustained through substitutabilities: we are already faced with path-dependent time-lags in ecological decline due to historical transformation of habitats globally; reductions in existing habitat are likely to induce reductions in species complement that are nonlinear, meaning that the full consequences of losses may not be factored into any offsetting calculations; and broader climate change makes predictable restorations and creations of future habitat increasingly difficult to enact with any certainty. More challenging still are the sheer complexities proffered by the diversities and dynamics embraced by a more processual and relational understanding of life lived by lives. Ecosystems themselves are chimerical, their ontology "shifting and elusive, driven by the vagaries of ecological inquiry" to appear as "artifacts of the methods of the science investigating them, not robustly existing independent entities" (Baird Callicott 2013: 106). Organisms, including the human body, do not exist as autonomous units, but as resolutely relational beings-becomings, comprised internally of interacting microorganisms and dependent for existence on relationships with and ingestions of multiplicitous more-thanhuman others (Baird Callicott 2013: 107; Margulis 1998).

This intractable complexity notwithstanding, aggregate rules, such as those summarised above, suggest that destruction can occur for one 'element' of 'natural capital' as long as it is substituted or compensated for within the terms and frames set by the aggregate rule. In carbon accounting this approach supports the mitigation of industrial emissions through purchase of offset credits signalling sequestration somewhere else. In biodiversity management, aggregate rules support biodiversity offsetting strategies that seem to offer a possibility of generating 'no net loss' of 'biodiversity', even though they exist by virtue of a measurable loss of individuals of species through development impact. Strategies of 'offsetting' and 'no net loss' are therefore considered in the next sub-section.

\section{'Offsetting' and 'no net loss'}

The 'aggregate natural capital rule' and 'net zero carbon neutrality' consolidate an ontological frame that permits different units of nature in different places and times to be exchanged for each other, as long as some aggregate measure for a spatial and/or temporal scale of analysis apparently remains intact. Contemporary market-based 'green economy' approaches to the management of environmental degradation are thereby able to emphasise exchanges whereby quantified units of environmental harm such as carbon credits, species credits and biodiversity offset units are 'offset' for compensating units of environmental health at different places, as well as at projected future times. ${ }^{16}$ Combined with aggregate rules and the aspiration of 'no net loss', offsetting principles and procedures act so as to do two key things:

1. They open possibilities for the technical establishment of equivalences and commensurabilities between entities that other ontological modes would retain as distinct (see sections 1 and 2); and

2. they have the effect of not addressing the identified cause of the problem in itself.

The damage that is to be 'solved' through the offset is thus sustained rather than reduced or eliminated.

A number of authors (see, for example, the collection edited by Weintrobe 2013) have utilised the psychoanalytic concept of 'disavowal' to theorise offsetting as an approach to acknowledged loss so as (seemingly) to generate 'no net loss' in aggregate. I have found it useful to go back to Freud's original 1938 essay on 'disavowal' entitled 'Splitting of the ego in the process of defence' (Freud 2009(1938)). In this, Freud asserts that in order to accommodate traumatic and dangerous reality the ego may behave in remarkable - he says artful - ways. In short, a defensive splitting can be effected such that the threat associated with particular behaviours is both acknowledged and systematically turned away from. Attention instead is directed towards fetishized solutions that in fact facilitate continuation of the dangerous but satisfying behaviour. Freud uses the

\footnotetext{
${ }^{16}$ Through the use of insurance to pay for the risk of a biodiversity offset not manifesting in the future in the way that it should in order to satisfy the conditions that would make it an offset (discussed in Sullivan 2013c: 86).
} 
term 'disavowal' to describe this simultaneous and symptomatic defence against, and displaced acknowledgement, of traumatic reality (Freud 2009(1938)). Disavowal thus is embodied in the fetishized substitute (for example, the offset), on to which value has been displaced or transferred. Or from a Lacanian perspective, the offset itself is symptomatic of acknowledgement of the Real of environmental crisis, dealt with through a fantastical and fetishized solution that functions ideologically to simultaneously disavow this 'Real' (Fletcher 2013).

Disavowal is, I think, exactly what we see in offsetting as a strategy for solving environmental problems. Through this strategy, the proliferation of attention, activity and strategies for creating offsets and offset markets seems at the same time to reduce engagement with the causes of degradation underscoring the apparent need for offsets. The offset, and its chimerical promise of 'no net loss', or even 'net gain', deriving from loss (cf. Sullivan and Hannis 2015), has become the fetishized substitute for facing and reducing the cause of environmental pathology. It is a defence erected socially and politically, perhaps so as to avoid facing the trauma of the broken socioecological systems that are the fallout of modern industrial effort, whilst permitting the simultaneous avoidance of behavioural choices that might act to reduce this trauma. The defence of the collective capitalist ego (if it's possible to speak of such a thing) is thereby sustained precisely through deepening the rift between acknowledged danger and the substitute 'solutions' that mask this danger a rift that is on a course for further deepening through discourses of 'decoupling', as considered below. In psychoanalytic terms such intensified splitting arguably engenders conditions ripe for psychosis - for a disavowal of reality that becomes both cynical and pathological.

\section{Decoupling}

Aggregate rules and offsetting are approaches towards conceptualising socio-environmental phenomena and solutions to environmental crisis without foundationally addressing the political economy causes of crisis. They are complemented by a third element: an intensified discourse of 'decoupling' (discussed in detail in Fletcher and Rammelt 2016). Decoupling refers to the process of seemingly disconnecting economic activity and particularly growth from environmental impacts, so as to 'dematerialise' economic growth (UNEP 2011). The core impetus is to sustain economic activity, especially economic growth, whilst simultaneously reducing the throughput of material environmental resources that contributes to this growth. This is the magical formula that will generate 'green growth.' As such, 'decoupling' moves in the opposite direction to 'degrowth' arguments (e.g. Kallis et al. 2012). Space does not permit a detailed exposition of these arguments. In brief, however, 'degrowth' positions also recognise that environmental impacts are related to economic productivity and consumption, but affirm the impossibility of decoupling economic activity from ecology under any scenario. This leads degrowth exponents to emphasise reductions in economic production and consumption so as to re-embed economic activity within ecological parameters. Simultaneously, radical redistributions of wealth and welfare are considered necessary by many to ameliorate both the ecological implications and societal instabilities caused by extreme wealth inequality (see analyses in Dorling 2015; Mikkelson et al. 2007; Moore 2015; Piketty 2014).

As with the discussion of offsetting and the goal of 'no net loss' above, Fletcher (2014b) analyses decoupling as a core fantasy of neoliberal environmental governance whose 'purpose' obfuscates the impossibility of succeeding in the reconciliation of ecological sustainability with long-term economic growth. This 'impossibility' notwithstanding, it remains interesting to consider what is going on with decoupling as an aspiration. Decoupling means to separate, disengage, or dissociate (something) from something else. ${ }^{17}$ In the techno-utopian modernist idea of disengaging economic activity from ecological effects (cf. Asafu-Adjaye et al. 2015) an additional and very familiar separation - that of society from nature - is also affirmed. As such, decoupling can be seen to be a logical extension, as opposed to a dismantling, of the old conceptual Cartesian divide. Through infusing logics of 'capital' further into conceptions and constructions of 'nature' (see Sullivan

\footnotetext{
${ }^{17}$ The second Google online definition that appeared when I looked up 'decoupling' states that to decouple also means to "muffle the sound or shock of (a nuclear explosion) by causing it to take place in an underground cavity." This should perhaps give cause for thought regarding what exactly the discourse of 'decoupling' in environmental management may be concealing.
} 
2013a, b), the conceptual disembedding of social lives from environmental contexts via the market economy is thereby deepened (as noted by Polanyi (2001(1944)), as is an impetus towards environmental management by 'remote control' (as cautioned by Guattari (2000(1989)) (see Sullivan 2010). It would be harder to imagine a stronger counter-move to a broader 'green' desire to (re)connect and (re)embed social relationships with the immanent materialities of other-than-human-natures.

These aspirations - conceptualising specific environmental parameters in aggregates, offsetting losses with gains of environmental elements composing these aggregates, and decoupling socio-economic activity from environmental materiality - are based on a disconnected and disembedded ontology that seems remarkable for its sheer distancing from the diversely immanent and embodied natures with which we live. All these strategies require technical renderings (cf. Murray Li 2007) of natures-beyond-the human into the categories and units that shore-up the monetary value regime and mode of rationality permitting neoclassical market economics to make sense. As well as being the expert and technical means via which other rationalities and ways of knowing are thereby sublimated, calculative rationality and monetised accounting practices act ontologically to structure in advance how it is possible to know natures-beyond-the-human. In doing so, other onto-epistemological possibilities for 'knowing nature' and conceptualising socioenvironmental issues are foreclosed (cf. Feyerabend 1999; Moreno et al. 2015; Nightingale 2016; Sullivan 2010, 2013a).

This tendency is connected to the situation we appear to find ourselves in, in which nothing is more valuable than money. What I mean by this is that apparently nothing can be valued, and no behaviours can be adjusted, if these are outside the calculable monetary sphere. As economists are keen to tell us, if something is without a price then it has zero-value (cf. Helm 2015). But this seems equivalent to saying that life, if it cannot be priced, merely exists as an externality to market economy. This surely cannot be right.

From an ethical perspective, calculating and accounting for all nature aspects in terms of quantified monetary forms of value (whether this is metaphorical or through constructions of nature as commoditised units and entities) seems disastrous. This is because such calculations place 'nature' into a value sphere - the sphere of money - whose entities are both endlessly exchangeable and beyond moral considerability. We can talk about harming other selves, whether these are other human or beyond-human selves, and we can have an expanded conception of the ecology of selves that might thus be harmed. But it would be strange indeed to talking about harming money. When we hook the category nature to the category capital, thereby configuring 'health' and 'harm' in terms of monetary signals only, we once more seem to loosen the possibility of relating with diverse other-than-human entities as communicative, flourishing beings who suffer as a result of being harmed.

\section{Truth/knowledge/power - and ontology - in political ecology}

Which brings me back to ontology. The elements of neoliberal green economy structuring considered above approach the diverse ecology of selves present with us here on earth through a series of totalities that flatten diversity, thereby entrenching the distance between 'us' and the 'its' of nature. These totalities include the ontological categories of 'nature' and ironically of 'biodiversity' (see especially Maier 2013; also Martin et al. 2013), and increasingly of 'natural capital', 'ecosystem services' and 'carbon.' Once in place, these totalizations denote and determine the technical and epistemological procedures by which their constituents can be known in advance. And so the individual and connected lives in a locality become abstracted and calculated as biodiversity offset units; and the entities constituting an old-growth tropical forest - some of which may be hundreds of years old and thus have 'witnessed' far more history than we have - become known as exchangeable particles of carbon. These renderings are making it harder than ever for 'us' to be in multifaceted relationships - including those imbued with wonder (Scott 2013) - with the distinctive and particular lives comprising nonhuman nature; at a time when perhaps a reconsideration of the nature of human 
relationships with the diverse entities we share life with is most urgently needed. ${ }^{18}$ As Joronen (2013: 635, 633) writes, this particular "ontological mono-politics of calculative enframing" "turns the world into a calculated picture denying what remains most essential for the earth: its openness for unpredictable emergence." In particular, the abstracting and calculative onto-epistemology of modern environmental accounting rigidifies the veil between 'us' and 'nature': an act depicted so well by William Blake in his 1795 iconic image of Isaac Newton turning his back on the immanent and animate complexity of the natures from which his will to abstract the laws of nature derived (see Figure 3). ${ }^{19}$

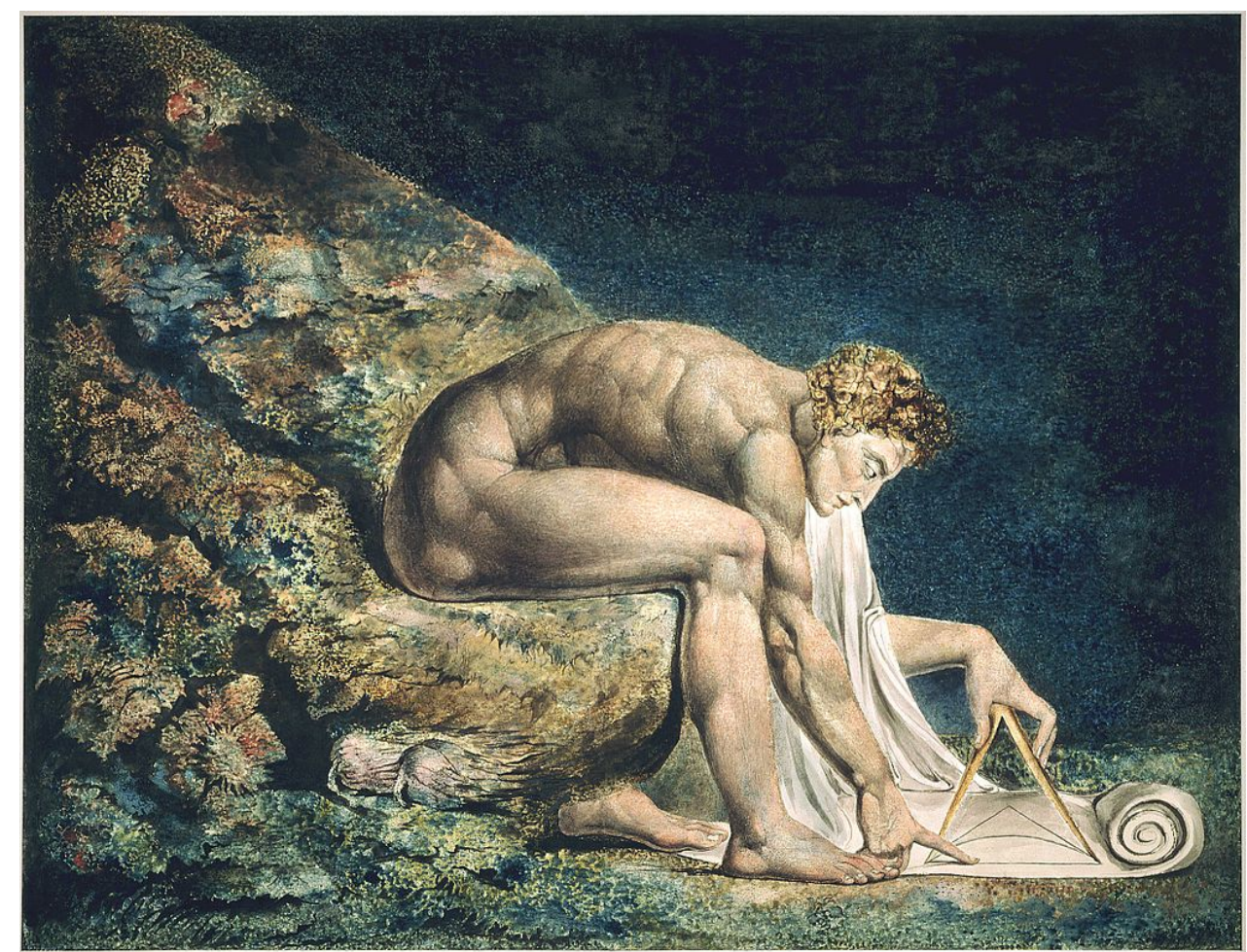

Figure 3: 'Newton' by William Blake (1795). Photographic reproduction of a two-dimensional, public domain work of art housed in the Tate Gallery, London, UK. Source: https://commons.wikimedia.org/wiki/Category:Newton_\%28Blake\%29\#/media/File:NewtonWilliamBlake.jpg,

Inspired by a Foucaultian approach toward subjugated knowledges, the situatedness of truth claims, and the always-present emancipatory possibility of change, political ecology has been powerful in exposing the workings of techno-managerial environmental discourses and the roles these play in the making of environmental subjects, as well as in the liberations and resistances contesting this disciplining. The explicit intention to work at the political and politicised edges of environmental thought in and of itself speaks of sensitivity to the situatedness of truth-claims regarding environmental phenomena - the understanding that the traction of such claims in society is related to historically-embedded institutions, associated techniques of power and the incidence of resistance. This perspective thus accepts that 'facts' are as hard as the evidence that

\footnotetext{
${ }^{18}$ I thus do not concur with Zizek (2011: 291) who argues that "[t]hat very [universalizing] force of abstraction which dissolves organic lifeworlds is simultaneously the resource of emancipatory politics."

${ }^{19}$ See http://www.tate.org.uk/art/artworks/blake-newton-n05058 (last accessed 16 December 2015).
} 
supports them and the methods through which they have been generated, but are also connected with the structural conditions and contexts of their making and are associated with various power-effects through their societal usage. What is considered to be 'truth', therefore, is always the outcome of dialogue, agreement, thought and reflection, access to artefacts, texts and archives, accepted methodologies, and so on, all of which arise in historical and socio-cultural contexts.

'Truths' regarding ontology are also inside and made through this dynamic, rather than somehow outside it. Such truths - including those in science as a particular modality for the acquisition and verification of truth claims - have changed constantly through history, alerting us to their world-making and socially constructive characteristics. If 'ontology' is understood simply as discourse on the nature of being (as encouraged by Graeber 2015) then it seems clear that indeed there are and have been multiple discourses on the nature of being (see Descola 2013). Whilst there may be only one singular true underlying nature of being, it seems that whoever has the say on what this is and how it might be known does so with the help of particular power relations accompanied by specific rules of verification, rather than by any particular direct access to The Truth.

What I have tried to draw out in this article, then, is that differences in environmental knowledges also relate to ontology: to discourses regarding how the world is constituted, which create variety in the nature of being and how this can be both known and encountered. As Blaser (2013) articulates, environmental conflicts - the heart of political ecology - are 'politicoconceptual problems', as much as they are struggles over land and 'natural resources' as property, and over discourses regarding how these properties should best be managed for economic and ecological ends. Importantly, a sensitivity to the ontological politics through which spaces and entities are defined and known, and which thereby shape environmental conflicts, may be key to recognising and understanding with more depth the significantly different 'natures' being struggled over in such conflicts (Blaser 2013; Escobar 2008; Joronen 2013; Martin et al. 2013).

Such ontological diversity and fluidity, however, makes things interesting in relation to truth values, truth claims and how 'we' might know that something is true or false, a dimension heightened in the current socio-political moment of so-called 'post-truth politics.' 20 'Truth' appears to be increasingly capricious and open to manipulation, as illustrated in the cartoons in Figure 4. Appearing in 2004 and 2016, each of these images shows a prominent US Republican politician asking Plato to agree that 'truth can be created by the repetition of a lie.' The cartoons allude to the 'manufacture of consent' (cf. Herman and Chomsky 1988) occurring as people are repetitively fed untruths (aka 'false news') that empower particular policies. The politicians in question are Karl Rove on the left, former Deputy Chief of Staff to President G.W. Bush described by some as the brains behind the Bush administration's repeated but untruthful claims that a weapons of mass destruction program existed in Iraq in $2003^{21}$, claims legitimizing an aggressive war in this country that contributed to current regional instability. US President Donald Trump, whose presidential campaign was filled with and fuelled hatred perpetuating lies, asks the same question on the right. Abhorrent 'truths' justifying equally abhorrent practices are perhaps an intrinsic aspect of human history, necessitating a corresponding urgency of resisting truth claims that lead systematically to unfreedoms and objectionable practices (cf. Foucault 2011(1983-1984)).

Indeed, an understanding that truth claims, including claims regarding ontology, arise and are negotiated amidst their own conditions of possibility strengthens, rather than weakens, the possibility of ethical critique and action regarding objectionable discourses and applied politics based on equally objectionable truth claims. Or to quote Foucault in his 1982 essay 'Why study power? The question of the subject', we need to check both "the type of reality with which we are dealing" and the historical conditions which motivate our conceptualization" of this type of reality - if we wish to both understand and to adjust the power-effects that are thereby amplified. The problem and encouragement, then, is to play the games of truth and the games of power with which these are imbricated, always with as little domination as possible (Foucault 2000(1984): 298). This set of assertions make it possible to critique and/or affirm particular "types

\footnotetext{
${ }^{20}$ A simple illustration of this concern is that 'post-truth' was named by Oxford Dictionaries as the 'word of the year' that most captured the mood of 2016 (Flood 2016).

${ }^{21}$ See, for example, http://www.bushsbrain.com/.
} 
of reality" for the power-effects they are perceived to amplify, without simultaneously asserting that any of these are 'The Truth' (also see Szerszynski 2007: 352).
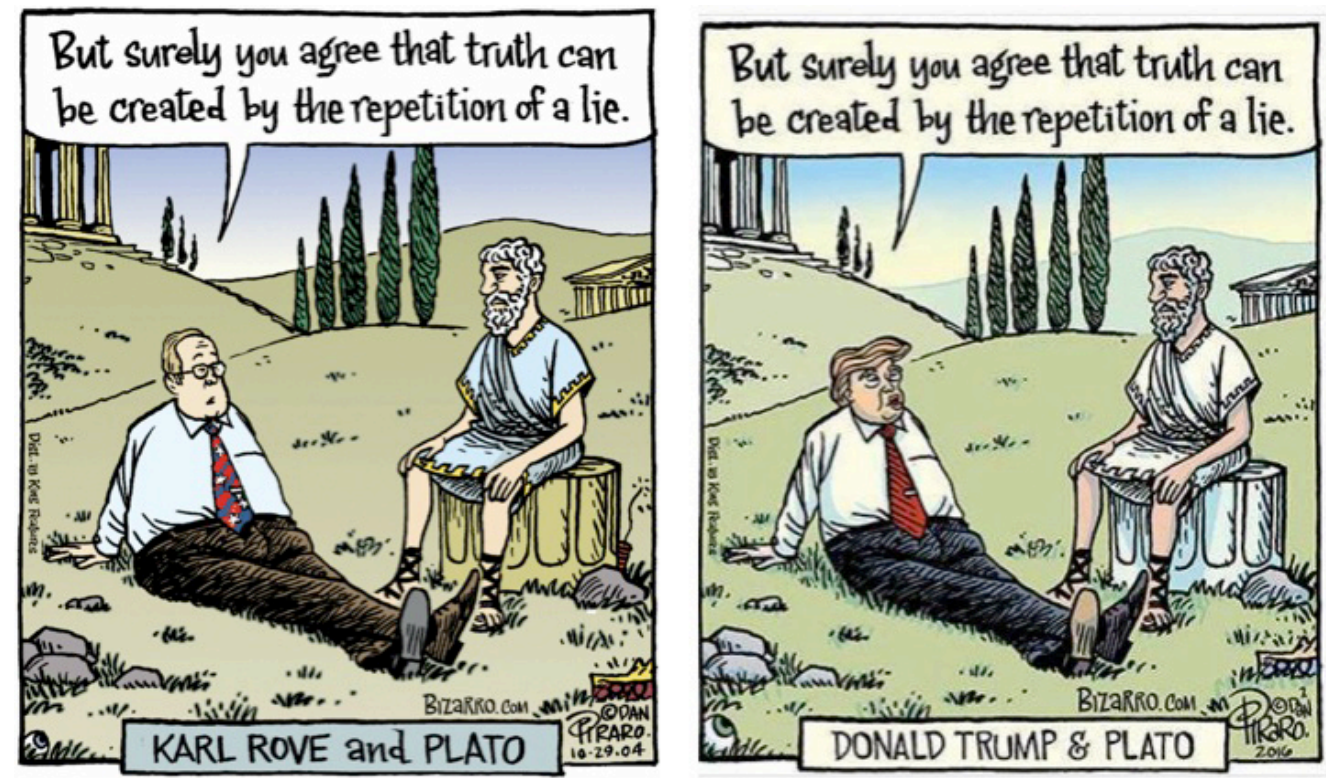

Figure 4: The theme of lies being acted on as 'truths' in politics has long been a target for journalists, civil society and satirists alike, as illustrated in these two cartoons from 2004 and 2016 of US Republican politicians asking Plato to agree that 'truth can be created by the repetition of a lie' (see discussion in text). Source: Dan Piraro (www.bizarro.com), used with permission.

Foucault (2011(1983-84)) in his later work wrote of the courage required so as to speak one's truth truthfully, knowing there may be a risk associated with doing this: what the ancient Greeks called parrhēsia in contradistinction to the manipulations of one's audience valued in rhetorical skill. Approaching and knowing the world differently to the empowered and instrumental order of things is risky and delicate business, as those resisting the frequently militarized advance of capitalist value orderings have always known. Political ecologists have work to do - to bear witness to, and intervene in, this risky and sometimes dangerous business. Opening to ontological variety in the perceived and known natures of the world is a further route through which political ecologists might sharpen our sensitivities to the existence of different ecological 'truths' and their defense. In doing so we might better play and refract the games of truth infusing practices of domination in socio-environmental relations.

\section{References}

Abram, D. 2010. Becoming animal: an earthly cosmology. New York: Pantheon Books.

Adger, N., T.A. Benjaminsen, K. Brown and H. Svarstad 2001 Advancing a political ecology of global environmental discourses. Development and Change 32 (4): 681-715.

Århem, K. 1996. The cosmic food web: human-nature relatedness in the Northwest Amazon. In Descola, P. and G. Pálsson (eds.) Nature and society: anthropological perspectives. London: Routledge. Pp. 185204, 
Asafu-Adjaye, J., L. Blomquist, S. Brand, B.W. Brook, R. Defries, E. Ellis, C. Foreman, D. Keith, M. Lewis, M. Lynas, T. Nordhaus, R. Pielke, R. Pritzker, J. Roy, M. Sagoff, M. Shellenberger, R. Stone and P. Teague. 2015. An ecomodernist manifesto. www.ecomodernism.org/

Asdal, K. 2008. Enacting things through numbers: taking nature into account/ing. Geoforum 39: $123-132$. Researchgate

Baird Callicott, J. 2013. Ecology and moral ontology. In Gergandi, D. (ed.) The structural links between ecology, evolution and ethics: the virtuous epistemic circle. Boston: Boston Studies in the Philosophy of Science and Dordrecht: Springer. Pp. 101-116.

Benjaminsen, T.A. 1993. Fuelwood and desertification: Sahel orthodoxies discussed on the basis of field data from the Gourma region in Mali. Geoforum 24(4): 397-409.

Bennett, J. 2010. Vibrant matter: a political ecology of things. Durham: Duke University Press. Researchgate

Berlin, B. 2014(1992). Ethnobiological classification: principles of categorization of plants and animals in traditional societies. Princeton: Princeton University Press.

Blaser, M. 2013. Notes towards a political ontology of 'environmental' conflicts. In Green, L. (ed.) Contested ecologies: dialogues in the South on nature and knowledge. Cape Town: Human Sciences Research Council Press. Pp. 13-27.

Bowman, M.I. 2007. Ancient Avalon, New Jerusalem, heart chakra of planet Earth: the local and the global in Glastonbury. In Kemp, D. and J.R. Lewis (eds.) Handbook of New Age. Leiden: Brill. Pp. 291-314.

Brightman, M., V.E. Grotti and O. Ulturgasheva 2013. (eds.) Animism and invisible worlds: the place of nonhumans in indigenous ontologies. In Brightman, M., V.E. Grotti and O. Ulturgasheva. (eds.) Animism in rainforest and tundra: personhood, animals, plants and things in contemporary Amazonia and Siberia. Oxford: Berghahn. Pp. 1-27.

Bryant, R.L. and S. Bailey 1997. Third world political ecology. London: Routledge.

Callon, M. 2006. What does it mean to say economics is performative? CSI Working Papers Series 5. http://halshs.archives-ouvertes.fr/docs/00/09/15/96/PDF/WP_CSI_005.pdf.

Castree, N. 2003. Environmental issues: relational ontologies and hybrid politics. Progress in Human Geography 27(2): 203-211.

Chakrabarty, D. 2000. Provincializing Europe: postcolonial thought and historical difference. Princeton, New Jersey: Princeton University Press.

Clastres, P. 1990(1974). Society against the state: essays in political anthropology. New York: Zone Books.

Cavanagh, C.J. and T.A. Benjaminsen. 2014. Virtual nature, violent accumulation: The 'spectacular failure' of carbon offsetting at a Ugandan National Park. Geoforum 56: 55-65.

Cohen, E. 1986. Law, folklore and animal lore. Past and Present 110: 6-37.

Cook, B. 2013. Pursuing Eudaimonia: re-appropriating the Greek philosophical foundations of the Christian Apophatic tradition. Newcastle: Cambridge Scholars Publishing.

de Certeau, M. 2010. Heterologies: discourse on the other. Trans. by B. Massumi. Minneapolis: University of Minnesota Press.

Deleuze, G. and F. Guattari 1987(1980). A thousand plateaus: capitalism and schizophrenia, trans. Brian Massumi. London: The Athlone Press.

Descartes, R. 1968(1637). Discourse on method. London: Penguin Books.

Descartes, R. 2015(1649) The passions of the soul: and other late philosophical writings. Oxford: Oxford University Press.

Descola, P. 2013. Beyond nature and culture. Chicago: University of Chicago Press.

Descola, P. and G. Pálsson (eds.). 1996. Nature and society: anthropological perspectives. London: Routledge.

Dorling, D. 2015 Inequality and the 1\%. London: Verso.

Dransart, P. (ed.). 2013. Living beings: perspectives on interspecies engagements. London: Bloomsbury. 
Dunlap, A. and J. Fairhead 2014. The militarisation and marketisation of nature: an alternative lens to 'climate-conflict.' Geopolitics 19(4): 937-961.

Escobar, A. 2008. Territories of difference: place, movements, life, redes. Durham, NC: Duke University Press.

Evernden, N. 1985. The natural alien: humankind and environment. Toronto: University of Toronto Press.

Fairhead, J. and Leach, M. 1996 Misreading the African landscape: society and ecology in a forest-savanna mosaic. Cambridge: Cambridge University Press.

Feyerabend, P. 1999. Conquest of abundance: a tale of abstraction versus the richness of being. Chicago: Chicago University Press.

Felton, S. 2011. Tracking the Save the Rhino Trust. The Namibian. http://www.namibian.com.na/index.php?id=80961\&page=archive-read

Fletcher, R. 2013. How I learned to stop worrying and love the market: virtualism, disavowal, and public secrecy in neoliberal environmental conservation. Environment and Planning D: Society and Space 31(5): 796-812. Academia

Fletcher, R. 2014a. Taking the chocolate laxative: why neoliberal conservation 'fails forward.' In Büscher, B., W. Dressler and R. Fletcher (eds.) Nature ${ }^{\mathrm{TM}}$ Inc.: the new frontiers of environmental conservation. Tucson: University of Arizona Press. Pp. 87-107. Academia

Fletcher, R. and C. Rammelt 2016. Decoupling: a key fantasy of the post-2015 sustainable development agenda. Globalizations http://dx.doi.org/10.1080/14747731.2016.1263077

Flood, A. 2016. 'Post-truth' named word of the year by Oxford Dictionaries. The Guardian 15 November 2016 https://www.theguardian.com/books/2016/nov/15/post-truth-named-word-of-the-year-by-oxforddictionaries

Forsyth, T.J. 2001. Critical realism and political ecology. In Lopez, J. and G. Potter (eds.). After postmodernism: an introduction to critical realism. London: Athlone Press. Pp. 146-154.

Forsyth, T.J. 2003. Critical political ecology: the politics of environmental science. London: Routledge.

Foucault, M. 1970. The order of things. New York: Pantheon Books.

Foucault, M. 1980. Power/knowledge: selected interviews and other writings, 1972-1977 edited by C. Gordon. London: Harvester Wheatsheaf.

Foucault, M. 1982. The subject and power. Critical Enquiry 8(4): 777-795.

Foucault, M. 2000(1984). The ethics of the concern of the self as a practice of freedom (an interview with H. Becker, R. Formet-Betancourt, and A. Gomex-Müller). In Rabinow, P. (ed.). Ethics: subjectivity and truth. essential works of Foucault 1954-1984, vol. 1. London: Penguin. Pp. 146-154.

Foucault, M. 2011(1983-1984). The courage of truth: the government of self and others. Lectures at the Collège de France, 1983-1984, trans. G. Burchell. Godalming: Picador.

Freud, S. 2009(1938). Splitting of the ego in the process of defence. In Bokanowski, T. and S. Lewkovitz (eds.) On Freud's 'Splitting of the ego in the process of defence.' London: Karnac Books. Pp. 3-6.

Gorenflo, L.J., S. Romaine, R.A. Mittermeier and K. Walker-Painemilla 2012. Co-occurrence of linguistic and biological diversity in biodiversity hotspots and high biodiversity wilderness areas. Proceedings of the National Academy of Sciences 109(21): 8032-8037.

Graeber, D. 2015. Radical alterity is just another way of saying 'reality': a reply to Eduardo Viveiros de Castro. HAU: Journal of Ethnographic Theory 5 (2): 1-41.

Green, L. (ed.) 2013. Contested ecologies: dialogues in the south on nature and knowledge. Cape Town: Human Sciences Research Council Press.

Guattari, F. 2000(1989). The three ecologies. Trans. Ian Pindar and Paul Sutton. London: Continuum.

Haacke, W.H.G. and E.A. Eiseb 1999. Khoekhoegowab-English English-Khoekhoegowab glossary/midi saogub. Windhoek: Gamsberg Macmillan. 
Haacke, W.H.G. and E.A. Eiseb 2002. Khoekhoegowab dictionary with an English-Khoekhoegowab index. Windhoek: Gamsberg Macmillan.

Hall, M. 2011. Plants as persons: a philosophical botany. New York: SUNY Press.

Hallowell, I. 1960 Ojibwa ontology, behavior and world view. In Diamond, S. (ed.) Culture in history: essays in honour of Paul Radin. New York: Octagon Books. Pp. 19-52.

Hannis, M. 2015. The virtues of acknowledged ecological dependence. Environmental Values 24: 145-164.

Hannis, M. 2016. Freedom and environment: autonomy, human flourishing and the political philosophy of sustainability. London: Routledge.

Haraway, D. 2008. When species meet. Minneapolis: University of Minnesota Press.

Harvey, G. 2005. Animism: respecting the living world. London: Hurst and Co.

Head, L., J. Atchison and C. Phillips 2015. The distinctive capacities of plants: re-thinking difference via invasive species. Transactions of the Institute of British Geographers 40(3): 399-413.

Hecht, G. 2012. Being nuclear: Africans and the global uranium trade. Cambridge, Massachusetts: MIT Press.

Helm, D. 2014. Taking natural capital seriously. Oxford Review of Economic Policy 30(1): 109-125.

Helm, D. 2015. Natural capital: valuing the planet. London: Yale University Press.

Herman, E.S. and N. Chomsky. 1988. Manufacturing consent: the political economy of mass media. New York: Pantheon Books.

Herodotus 1998. The histories, trans. by R. Waterfield. Oxford: Oxford University Press.

Holbraad, M., M.A. Pedersen, and E. Viveiros de Castro. 2014. The politics of ontology: anthropological positions. Cultural Anthropology Online, January 13, 2014.

Homewood, K. and A. Rodgers 1987. Pastoralism, conservation and the overgrazing controversy. In Anderson, D. and R. Grove (eds.). Conservation in Africa: people, policies and practice. Cambridge: Cambridge University Press. Pp. 111-128.

Hornborg, A. 2006. Animism, fetishism, and objectivism as strategies for knowing (or not knowing) the world. Ethnos: Journal of Anthropology 71(1): 21-32.

Ingold, T. 2000. The perception of the environment: essays in livelihood, dwelling and skill. London: Routledge.

Jackson, M. 2013. Plastic islands and processual grounds: ethics, ontology, and the matter of decay. Cultural Geographies 20(2): 205-224.

Jarosz, L. 2004 Political ecology as ethical practice. Political Geography 23: 917-927.

Johnson, C.M. 2008. The social ontology implicit in Wittgenstein. www.carlsensei.com/docs/essays/wittgenstein-and-watsuji.pdf

Joronen, M. 2013. Heidegger, event and the ontological politics of the site. Transactions of the Institute of British Geographers 38: 627-638.

Kallis, G., C. Kerschner and J. Martinez-Alier 2012. The economics of degrowth. Ecological Economics 84: 172-180.

Kambatuku, J. 1996. Historical profile of farms in former Damaraland: notes from the archival files. DRFN (Desert Research Foundation of Namibia) Occasional Paper 4.

Kohn, E. 2013. How forests think: towards an anthropology of nature beyond the human. Berkeley: University of California Press.

Kuhn, T.S. 1970(1962). The structure of scientific revolutions. Second Edition. Chicago: University of Chicago Press.

Lakoff, G. 2010. Why it matters how we frame the environment. Environmental Communication: a Journal of Nature and Culture 4(1): 70-81.

Latour, B. 2007. Reassembling the social: an introduction to actor-network-theory. Oxford: Oxford University Press. 
Latour, B. 2013. An inquiry into modes of existence: an anthropology of the moderns. Cambridge, M.A.: Harvard University Press.

Leach, M. and R. Mearns (eds.). 1996. The lie of the land: challenging received wisdom on the African environment. Oxford: James Currey.

Lohmann, L. 2009. Toward a different debate in environmental accounting: the cases of carbon and costbenefit. Accounting, Organizations and Society 34: 499-534.

Low, C. 2008 Khoisan medicine in history and practice. Rüdiger Köppe Verlag: Köln.

Lukacs, M. 2015. Indigenous activists take to Seine river to protest axing of rights from Paris climate pact. The Guardian. http://www.theguardian.com/environment/true-north/2015/dec/07/indigenous-activiststake-to-seine-river-to-protest-axing-of-rights-from-paris-climate-pact

Mace, G. 2014. Towards a framework for defining and measuring changes in natural capital. NCC Working Paper. https://www.naturalcapitalcommittee.org/working-papers.html

Maier, D. 2013. What's so good about biodiversity? A call for better reasoning about nature's value. New York: Springer.

Malinowski, B. 1922. Argonauts of the western Pacific. London: Routledge and Kegan Paul.

Marder, M. 2013. Plant-thinking: a philosophy of vegetal life. New York: Columbia University Press.

Margulis, L. 1998. Symbiotic planet: a new look at evolution. New York: Basic Books.

Martin, A., S. McGuire and S. Sullivan 2013. Global environmental justice and biodiversity conservation. The Geographical Journal 179(2): 122-131.

Massumi, B. 2014. What animals teach us about politics. Durham, NC: Duke University Press.

Miescher, G. 2012. Namibia's red line: the history of a veterinary and settlement border. New York: Palgrave Macmillan.

Mikkelson, G.M., A. Gonzalez and G.D. Peterson 2007. Economic inequality predicts biodiversity loss. PLoS ONE 2(5): e444. doi:10.1371/journal.pone.0000444

Mol, A. 2002. The body multiple: ontology in medical practice. London: Duke University Press.

Moore, J. 2015 Nature in the limits to capital (and vice versa). Radical Philosophy 193: 9-19.

Moreno, C., D.S. Chassé and L. Fuhr. 2015. Carbon metrics: global abstractions and ecological epistemicide. Berlin: Heinrich-Böll-Stiftung.

Murray Li, T.M. 2007. The will to improve: governmentality, development and the practice of politics. Durham: Duke University Press.

Nightingale, A. 2016. Adaptive scholarship and situated knowledges? Hybrid methodologies and plural epistemologies in climate change adaptation research. Area 48(1): 41-47.

Pawliczek, J. and S. Sullivan 2011. Conservation and concealment in SpeciesBanking.com, US: an analysis of neoliberal performance in the species offsetting industry. Environmental Conservation 38(4): 435-444.

Pellis, A. 2011. Modern and traditional arrangements in community-based tourism: exploring an election conflict in the Anabeb Conservancy, Namibia. In van der Duim, R., D. Meyer, J. Saarinen and K. Zellmer (eds.) New alliances for tourism, conservation and development in eastern and southern Africa. Delft: Eburon. Pp. 127-145.

Pellis, A., M. Duineveld and L.B. Wagner 2015. Conflicts forever: the path dependencies of tourism conflicts: the case of Anabeb Conservancy, Namibia. In Jóhannesson, G.T., C. Ren and R. van der Duim (eds.) Tourism encounters and controversies: ontological politics of tourism development. Abingdon: Ashgate. Pp. 115-138.

Piketty, T. 2014. Capital in the Twenty-First century. Cambridge, MA: Harvard University Press.

Polanyi, K. 2001(1944). The great transformation: the political and economic origins of our time. Boston: Beacon Press.

Plumwood, V. 2006. Feminism and the mastery of nature. London: Routledge. 
Read, R. 2012. Wittgenstein amongst the sciences: Wittgensteinian investigations into the 'scientific method.' Farnham: Ashgate.

Reyes, O. 2015. Seven flies in the ointment of the Paris climate deal euphoria. http://www.globaljustice.org.uk/blog/2015/dec/15/seven-flies-ointment-paris-climate-deal-euphoria

Richards, P. 1985 Indigenous agricultural revolution. London: HarperCollins Publishers Ltd.

Robbins, P., J. Hintz and S.A. Moore 2010 Environment and society: a critical introduction. Chichester: Wiley-Blackwell.

Schmidt, S. (ed.) 2011. Hai |lom and !Xû stories from north Namibia: collected and translated by Terttu Heikkinen (1934-1988). Köln: Rüdiger Köppe Verlag.

Schmidt, S. 2014a. Spirits: some thoughts on ancient Damara folk belief. Journal of the Namibian Scientific Society 62: 133-160.

Schmidt, S. 2014b. Some notes on the so-called Heitsi-Eibeb graves in Namibia: ancient heaps of stones at the roadside. BAB Working Paper 3. baslerafrika.ch/wp-content/uploads/WP-2014-3-Schmidt.pdf

Schneider, L. and A. Kollmuss 2015. Perverse effects of carbon markets on HFC-23 and $\mathrm{SF}_{6}$ abatement projects in Russia. Nature Climate Change 5: 1061-1063.

Scott, M.W. 2013. The anthropology of ontology (religious science). Journal of the Royal Anthropological Institute (N.S.) 19: 859-872.

Scott Cato, M. 2012. The bioregional economy: land, liberty and the pursuit of happiness. London: Earthscan.

Smith, H. 1981. Four cultures: the ontological turn. Syracuse Scholar (1979-1991) 2(1): Article 13, online. http://surface.syr.edu/suscholar/vol2/iss1/13

Sokal, A. and J. Bricmont 1998. Intellectual impostures. London: Profile Books.

Sontag, S. 1963. The Benefactor. New York: Farrar, Straus and Giroux.

Steffen, W., W. Broadgate, L. Deutsch, O. Gaffney and C. Ludwig 2015. The trajectory of the Anthropocene: the great acceleration. The Anthropocene Review 2(1): 81-98.

Stott, P. and S. Sullivan 2000. Political ecology: science, myth and power. London: Edward Arnold.

Sullivan, S. 1999. Folk and formal, local and national: Damara cultural knowledge and community-based conservation in southern Kunene, Namibia. Cimbebasia 15: 1-28.

Sullivan, S. 2000. Getting the science right, or introducing science in the first place? Local 'facts', global discourse - 'desertification' in north-west Namibia. In Stott, P. and S. Sullivan (eds.) Political ecology: science, myth and power. London: Edward Arnold. Pp. 15-44.

Sullivan, S. 2002. How sustainable is the communalising discourse of 'new' conservation? The masking of difference, inequality and aspiration in the fledgling 'conservancies' of Namibia. In Chatty, D. and M. Colchester (eds.) Conservation and mobile indigenous people: displacement, forced settlement and sustainable development. Oxford: Berghahn Press. Pp. 158-187.

Sullivan, S. 2003. Protest, conflict and litigation: dissent or libel in resistance to a conservancy in north-west Namibia. In Berglund, E. and D. Anderson (eds.) Ethnographies of conservation: environmentalism and the distribution of privilege. Oxford: Berghahn Press. Pp. 69-86.

Sullivan, S. 2006. The elephant in the room? Problematizing 'new' (neoliberal) biodiversity conservation. Forum for Development Studies 33(1): 105-135.

Sullivan, S. 2009. Green capitalism, and the cultural poverty of constructing nature as service-provider. Radical Anthropology 3: 18-27.

Sullivan, S. 2010. 'Ecosystem service commodities' - a new imperial ecology? Implications for animist immanent ecologies, with Deleuze and Guattari. New Formations: a Journal of Culture/Theory/Politics 69: 111-128.

Sullivan, S. 2013a. Nature on the move III: (re)countenancing an animate nature. New Proposals: Journal of Marxism and Interdisciplinary Enquiry 6(1-2): 50-71. 
Sullivan, S. 2013b. Banking nature? The spectacular financialisation of environmental conservation. Antipode 45(1): 198-217.

Sullivan, S. 2013c. After the green rush? Biodiversity offsets, uranium power and the 'calculus of casualties' in greening growth. Human Geography 6(1): 80-101.

Sullivan, S. 2014. The natural capital myth; or will accounting save the world? Preliminary thoughts on nature, finance and values. LCSV Working Paper 3 http://thestudyofvalue.org/wpcontent/uploads/2013/11/WP3-Sullivan-2014-Natural-Capital-Myth.pdf

Sullivan, S. 2015. On climate change ontologies and the spirit(s) of oil. SPERI (Sheffield Political Economy Research Institute) spotlight on the UN climate summit II, 19 November 2015 http://speri.dept.shef.ac.uk/2015/11/19/speri-spotlight-on-the-un-climate-summit-part-2/

Sullivan, S. 2016a. (Re-)embodying which body? Philosophical, cross-cultural and personal reflections on corporeality. In Thomas-Pellicer, R., de Lucia, V. and Sullivan, S. (eds.) Law, philosophy and ecology: exploring re-embodiments. London: GlassHouse Books. Pp. 119-138.

Sullivan, S. 2016b. What's ontology got to do with it? On the knowledge of nature and the nature of knowledge in environmental anthropology. In Kopnina, H. and Shoreman-Ouimet, E. (eds.) Routledge international handbook of environmental anthropology. London: Routledge. Pp. 155-169.

Sullivan, S. in press 2017. Review essay: 'Natural capital', 'fairy-tales' and ideology. Development and Change 48(2).

Sullivan, S. and M. Hannis 2015. Nets and frames, losses and gains: value struggles in engagements with biodiversity offsetting policy in England. Ecosystem Services 15: 162-173.

Sullivan, S. and M. Hannis 2016. Relationality, reciprocity and flourishing in an African landscape: perspectives on agency amongst ||Khao-a Dama, !Narenin and ||Ubun elders in west Namibia. Future Pasts Working Papers no. 2. http://www.futurepasts.net/fpwp2-sullivan-hannis-2016

Sullivan, S., M. Hannis, A. Impey, C. Low and R.F. Rohde 2016. Future pasts? sustainabilities in west Namibia - a conceptual framework for research. Future Pasts Working Papers No. 1 http://www.futurepasts.net/fpwp1-sullivan-et-al-2016

Sullivan, S. and C. Low 2014. Shades of the rainbow serpent? A KhoeSān animal between myth and landscape in southern Africa - ethnographic contextualisations of rock art representations. Arts 3(2): 215-244.

Szerszynski, B. 2007. The post-ecologist condition: irony as symptom and cure. Environmental Politics 16(2): 337-355.

Tinley, K.L. 1971. The case for saving Etosha. African Wild Life (supplement) 25: 3-14.

Tsing, A. 2005. Friction: an ethnography of global connection. Oxford: Princeton University Press.

Tsing, A. 2014. Wreckage and recovery: four papers exploring the nature of nature. AURA Working Papers vol. 2. Arhus University. Pp. 2-15.

UNEP 2011. Decoupling natural resource use and environmental impacts: factsheet. UNEP: International Resource Panel.

Vigh, H.E. and D.B. Sausdal 2014 From essence back to existence: anthropology beyond the ontological turn. Anthropological Theory 14(1): 49-73.

Viveiros de Castro, E. 2004. Exchanging perspectives: the transformation of objects into subjects in Amerindian ontologies. Common Knowledge 10(3): 463-84.

Viveiros de Castro, E. 2013. Economic development and cosmopolitical re-involvement: from necessity to sufficiency. In Green, L. (ed.) 2013. Contested ecologies: dialogues in the south on nature and knowledge. Cape Town: Human Sciences Research Council Press. Pp. 28-40.

Weber, M. 2010(1930). The protestant ethic and the spirit of capitalism. London: Routledge.

Weintrobe, S. (ed.) 2013. Engaging with climate change: psychoanalytic and interdisciplinary perspectives. London: Routledge. 
Wheeler, W. 2006. The whole creature: complexity, biosemiotics and the evolution of culture. London: Lawrence \& Wishart Ltd.

Wittgenstein, L. 2001(1953). Philosophical investigations: the German text, with a revised English translation. $3^{\text {rd }}$ ed. Trans. G. E. M. Anscombe. Oxford: Blackwell Publishing.

Zimmer Bradley, B. 1993(1983). The mists of Avalon. London: Penguin.

Žižek, S. 2011. Living in the end times. London: Verso. 